EUGENIUSZ RYDZ

IWONA JAŻEWICZ

\title{
Przemiany strukturalne przemysłu na przykładzie małych miast Pomorza Środkowego
}

Zapoczątkowane po 1989 r. zmiany ustrojowe w Polsce oraz przejście do systemu gospodarki rynkowej wymagają nowego spojrzenia na funkcjonowanie zakładów przemysłowych w miastach, zwłaszcza najmniejszych jednostkach. Często bowiem w małych miastach przemysł pełnił wiodącą funkcję miastotwórczą (Żechowski 1973, Ginsbert-Gebert 1966).

Celem niniejszego wystapienia jest próba przedstawienia zróżnicowania poziomu rozwoju oraz struktury przemysłu w małych miastach Pomorza Środkowego w ujęciu przestrzennym, gałęziowym, wielkości oraz własności w świetle aktualnie trwających przeobrażeń społeczno-gospodarczych.

Przedmiotem zaś badań szczegółowych są małe miasta Pomorza Środkowego. W prezentowanym wystąpieniu za małe miasto przyjęto jednostki miejskie liczące mniej niż 20 tys. mieszkańców; taką granicę przyjmują m.in. M. Kiełczewska-Zaleska ( 1963 ), J. Rajman ( 1977 ) i E. Rydz ( 1981 ).

Dodatkowo zbiór małych miast podzielono na 3 kategorie wielkościowe: miasta liczące poniżej 5 tys. mieszkańców, 5 - 10 tys. mieszkańców i 10-20 tys. mieszkańców.

\section{Przestrzenne zróżnicowanie poziomu uprzemyslowienia małych miast}

Małe miasta Pomorza Środkowego są dość istotnie zróżnicowane pod względem uprzemysłowienia. Z przeprowadzonych dotychczas badań wynika, że zarówno przed, jak i w trakcie zachodzących przeobrażeń wyraźnie słabo uprzemysłowione są miasta najmniejsze, liczące poniżej 10 tys. mieszkańców (tab. 1). Przy czym stopień ich uprzemysłowienia uległ wyraźnemu obniżeniu w okresie transformacji gospodarczej. W 1998r. jedynie w Kępicach, Karlinie, Czaplinku oraz Bornem Sulinowie przypadało więcej niż 100 pracujących w przemyśle. W warunkach industrializacji preferującej budowę dużych zakładów przemysłowych, miasta tej klasy wielkości na ogół nie stwarzały korzyści z punktu widzenia lokalizacji przemysłu, przede wszystkim ze względu na słabe wyposażenie w urządzenia infrastruktury technicznej. Natomiast stopień uprzemysłowienia miast liczących powyżej 10 tys. mieszkańców jest nieco wyższy. 
Tab.1. Wybrane mierniki uprzemysłowienia małych miast Pomorza Środkowego w latach 1988-1998.

\begin{tabular}{|c|c|c|c|c|c|c|}
\hline \multirow{3}{*}{ Wyszczególnienie } & \multicolumn{3}{|c|}{$1988 \mathrm{r}$. } & \multicolumn{3}{|c|}{$1998 \mathrm{r}$. } \\
\hline & \multicolumn{2}{|c|}{$\begin{array}{l}\text { Zatrudnienie } \\
\text { w przemyśle }\end{array}$} & \multirow{2}{*}{$\begin{array}{c}\text { Zatrudnienie } \\
\text { w przemyśle } \\
\text { na } 1000 \\
\text { mieszkańców }\end{array}$} & \multicolumn{2}{|c|}{$\begin{array}{l}\text { Pracujący w działal- } \\
\text { ności produkcyjnej }\end{array}$} & \multirow{2}{*}{$\begin{array}{c}\text { Pracujacy w } \\
\text { działalności } \\
\text { produkcyjnej } \\
\text { na } 1000 \\
\text { mieszkańców }\end{array}$} \\
\hline & 1. b. & $\begin{array}{l}\text { \% ogółu za- } \\
\text { trudnionych }\end{array}$ & & l. b. & $\begin{array}{c}\text { \% ogółu } \\
\text { pracujących }\end{array}$ & \\
\hline $\begin{array}{l}\text { Miasta do } 5000 \\
\text { mieszkańców }\end{array}$ & 3080 & 34,3 & 114 & 2444 & 21,7 & 184 \\
\hline Barwice & 443 & 28,9 & 117 & 208 & 35,4 & 51 \\
\hline Biały Bór & 126 & 13,9 & 52 & 107 & 21,9 & 44 \\
\hline Bobolice & 355 & 24,3 & 70 & 146 & 11,5 & 31 \\
\hline Borne Sulinowo & - & - & - & 474 & 15,4 & 199 \\
\hline Kalisz Pomorski & 449 & 33,1 & 105 & 237 & 16,6 & 57 \\
\hline Kępice & 1045 & 67,4 & 252 & 633 & 55,8 & 148 \\
\hline Leba & 599 & 41,5 & 128 & 547 & 13,4 & 134 \\
\hline Polanow & 63 & 8,8 & 18 & 92 & 7,3 & 31 \\
\hline $\begin{array}{l}\text { Miasta } 5000-10000 \\
\text { mieszkańców }\end{array}$ & 5123 & 34,3 & 123 & 3057 & 24,7 & 75 \\
\hline Czaplinek & 1003 & 37,9 & 141 & 820 & 39,1 & 113 \\
\hline Czarne & 1544 & 53,2 & 261 & 320 & 12,4 & 49 \\
\hline Debrzno & 313 & 28,6 & 49 & 122 & 24,6 & 23 \\
\hline Karlino & 900 & 42,2 & 154 & 1013 & 54,8 & 170 \\
\hline Połczyn Zdrój & 746 & 16,9 & 64 & 468 & 9.9 & 50 \\
\hline Sianów & 617 & 35,7 & 96 & 314 & 30,1 & 48 \\
\hline $\begin{array}{l}\text { Miasta } 10000- \\
20000 \text { mieszkańców }\end{array}$ & $\begin{array}{c}1830 \\
2\end{array}$ & 34,9 & 129 & $\begin{array}{c}1276 \\
9\end{array}$ & 31,0 & 129 \\
\hline Bytów & 2253 & 29,7 & 115 & 2701 & 33,3 & 115 \\
\hline Czluchów & 2117 & 29,2 & 125 & 1697 & 29.9 & 125 \\
\hline Darłowo & 2584 & 50,4 & 160 & 1184 & 29,4 & 160 \\
\hline Drawsko Pomorskie & 1101 & 24,4 & 95 & 639 & 25,4 & 95 \\
\hline Miastko & 1829 & 31,9 & 144 & 1320 & 35,6 & 144 \\
\hline Sławno & 1880 & 29,6 & 127 & 1250 & 31,9 & 127 \\
\hline Świdwin & 1260 & 24,9 & 69 & 1283 & 25,7 & 69 \\
\hline Ustka & 3167 & 55,6 & 173 & 1427 & 38,2 & 173 \\
\hline Zlocieniec & 2111 & 41,8 & 148 & 1268 & 23,9 & 148 \\
\hline $\begin{array}{l}\text { Ogółem miasta } \\
\text { do } 20000 \\
\text { mieszkańców }\end{array}$ & $\begin{array}{c}2650 \\
5\end{array}$ & 34,8 & 126 & $\begin{array}{c}1827 \\
0\end{array}$ & 28,7 & 126 \\
\hline
\end{tabular}

Źródło: Tablice wynikowe. Zatrudnienie w gospodarce uspołecznionej województwa koszalińskiego i województwa słupskiego w podziale na miasta i gminy. WUS Koszalin 1988, WUS Shupsk 1988; Tablice wynikowe. Pracujący w gospodarce narodowej w miastach województwa koszalińskiego i słupskiego, System GRA, GUS, Warszawa 1998 


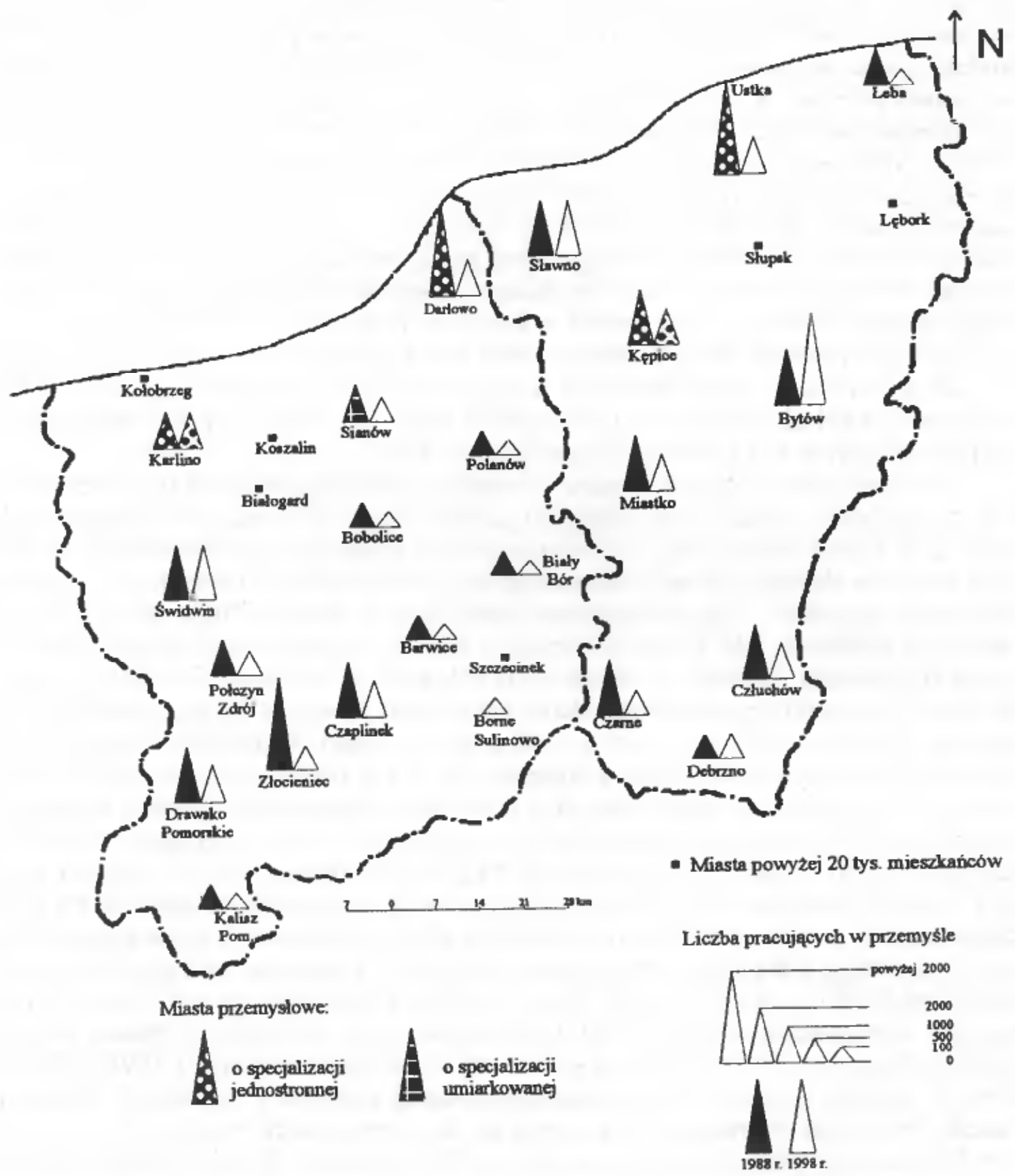

Ryc.1. Tendencje zmian funkcji przemysłowej malych miast Pomorza Środkowego w latach 1988-1998

Z przeprowadzonych badań wynika, że w 1988 r. przemysł stanowił funkcję miastotwórczą w 5 miastach (Karlino, Sianów, Darłowo, Ustka, Kępice), w tym 4 (Karlino, Darłowo, Ustka, Kępice) o jednostronnej i 1 (Sianów) o umiarkowanej specjalizacji (ryc. 1). Koncentrowały one 23,5 \% ogółu zatrudnienia przemysłowego w grupie egzogenicznej, ale 
obejmowały zaledwie $17,1 \%$ ogółu ludności miejskiej. Funkcje przemysłowe tych miast są pochodną aktywizacji gospodarczej z początku lat siedemdziesiątych. Zlokalizowanie zwłaszcza na terenie miast poniżej 10 tys. mieszkańców jednego dużego przedsiębiorstwa produkcyjnego powodowało, iż najistotniejszym elementem ich struktury funkcjonalnej pozostawał przemysł. Charakterystycznym przykładem są Kępice (Zakład Garbarski „Kegar" koncentrował 75,3 \% ogółu zatrudnionych), Karlino (w Zakładzie Płyt Wiórowych i Pilśniowych pracowało 72,3 \% ogółu zatrudnionych) czy Sianów (w Zakładach Przemysłu Zapałczanego pracowało 68,7 ogółu zatrudnionych). W przypadku Ustki czy Darłowa nadwyżki pracowników w przemyśle były wynikiem nagromadzenia $\mathrm{w}$ nich potencjału przemysłowego. W Ustce sektor egzogeniczny reprezentowały stocznia „Ustka”, Przedsiębiorstwo Połowów i Usług Rybackich „Korab” i Spółdzielnia Pracy Rybołówstwa Morskiego „Losoś”. Nadwyżki eksportowe w Darłowie pochodziły z Przedsiębiorstwa Połowów i Usług Rybackich „Kuter”, Fabryki Mebli oraz Fabryki Maszyn Rolniczych.

Obok jednostek o monocentrycznej funkcji przemysłowej znalazły się ośrodki, w których przemysł pełnił niewielką rolę. Przykładem mogą być Polanów ( $8,8 \%$ zatrudnionych w przemyśle), Biały Bór (13,9\%) i Połczyn Zdrój (16,9\%).

Zapoczątkowane w końcu lat osiemdziesiątych przeobrażenia społeczno-gospodarcze, a w szczególności ograniczenie monopolu państwowego, załamanie wschodniego rynku zbytu, a w konsekwencji całego systemu nakazowo-rozdzielczego doprowadziły do rozwoju procesów deindustrializacji zarówno biernej (zahamowanie inwestycji) jak i czynnej (likwidacja zakładów). Odzwierciedleniem zachodzących przemian było znaczne ograniczenie roli przemysłu jako głównego czynnika rozwoju gospodarczego małych miast Pomorza Środkowego. Zjawisko to potwierdzają obliczone w odniesieniu do 1998 r. wskaźniki (tab.1). Wymierną oznaką zmian okazał się wyraźny spadek liczby pracujących (z 26,5 tys. osób w 1988 r. do 18,3 tys. osób w 1998 r. w tym dziale). Szczególnie dotkliwie zaistniałe przeobrażenia odczuły miasta z podgrupy do 10 tys. mieszkańców, w których liczba pracujących w przemyśle zmniejszyła się o ponad $40 \%$. Analiza tego zjawiska w poszczególnych jednostkach wykazała największy bezwzględny ubytek w Czarnem (79,3\%), Bobolicach $(58,9 \%)$, Ustce $(55,0 \%)$, Darłowie $(54,2 \%)$, Barwicach $(53,1 \%)$, Sianowie $(49,8$ \%) i Kaliszu Pomorskim (47,3\%). Specyficzną cechą wymienionych ośrodków był w przeszłości wysoki poziom specjalizacji w jednym rodzaju działalności produkcyjnej, co potwierdziła analiza wskaźników specjalizacji względnej ${ }^{1 /}$. Załamanie bądź całkowite zaniechanie produkcji $\mathrm{z}$ reguły jednego, dużego zakładu przemysłowego we wspomnianych miastach doprowadziło do kryzysu ich bazy ekonomicznej, np. wskutek upadku Zakładu Produkcji Przyczep „AWROL” w Barwicach stopa bezrobocia wynosiła w 1998 r. 29,9 \%, a 39,2 \% ludności korzysta z pomocy opieki społecznej, podobnie w Bobolicach likwidacja Zakładu Przemysłu Wełnianego przyczyniła się do wzrostu stopy bezrobocia do $28,2 \%$, a 29,3 \% ludności miasta korzysta z pomocy opieki społecznej. Recesja działalności produkcyjnej okazała się na tyle niebezpieczna, że zmusiła samorządy lokalne miast (w obawie przed utratą podstaw egzystencji miast) do podjęcia działań promocyjnych, wyrażających się między innymi stwarzaniem preferencyjnych warunków kredytowych, podatkowych, udostępnieniem na dogodnych warunkach atrakcyjnych terenów miejskich i korzystnych obiektów na rozwój przedsiębiorczości w sferze usług. Mimo poczynionych zabiegów, miasta uprzemysłowione (Kępice, Karlino, Sianów, Czarne, Kalisz Pomorski) cechuje obecnie stagnacja, wysokie bezrobocie i wiele problemów ekologicznych (Rydz 1995). 
Do określenia tendencji zmian w koncentracji przemysłu w analizowanych jednostkach miejskich wykorzystano współczynnik redystrybucji ${ }^{2 /}$. Choć został on wyliczony dla stosunkowo krótkiego okresu, zaznaczyło się wyraźne jego zróżnicowanie w poszczególnych kategoriach wielkościowych miast (tab.2).

Tab.2. Wybrane mierniki struktury przestrzennej i gałęziowej przemysłu w małych miastach Pomorza Środkowego w latach 1988-1998

\begin{tabular}{|c|c|c|c|c|c|c|}
\hline Wyszczególnienie & $\begin{array}{l}\text { Współczyn- } \\
\text { nik koncen- } \\
\text { tracji teryto- } \\
\text { rialnej }\end{array}$ & $\begin{array}{l}\text { Współczyn- } \\
\text { nik koncen- } \\
\text { tracji demo- } \\
\text { graficznej }\end{array}$ & $\begin{array}{c}\text { Wspól- } \\
\text { czynnik } \\
\text { redystrybu- } \\
\text { cji }\end{array}$ & $\begin{array}{c}\text { Surowy } \\
\text { wskaźnik } \\
\text { Rodgersa }\end{array}$ & $\begin{array}{l}\text { Wyrow- } \\
\text { nany } \\
\text { wskaźnik } \\
\text { Rodgersa }\end{array}$ & $\begin{array}{l}\text { Współ- } \\
\text { czynnik } \\
\text { dywer- } \\
\text { syfika- } \\
\text { cji }\end{array}$ \\
\hline \multirow{2}{*}{\multicolumn{7}{|c|}{$\begin{array}{l}\text { Miasta do } 5000 \\
\text { mieszkańców }\end{array}$}} \\
\hline & & & & & & \\
\hline $1988 \mathrm{r}$ & 0,068 & 0,218 & $0,012^{a)}$ & 1246,9 & 0,638 & 60,8 \\
\hline $1998 \mathrm{r}$. & 0,092 & 0,215 & $0,019^{b)}$ & 1654,3 & 0,756 & 63,7 \\
\hline \multirow{2}{*}{\multicolumn{7}{|c|}{$\begin{array}{l}\text { Miasta } 5000-10000 \\
\text { mieszkańców }\end{array}$}} \\
\hline & & & & & & \\
\hline $1988 \mathrm{r}$ & 0,069 & 0,202 & $0,028^{a)}$ & 1544,2 & 0,699 & 68,3 \\
\hline $1998 \mathrm{r}$. & 0,089 & 0,221 & 0,035 & 1379,8 & 0,708 & 72,0 \\
\hline \multicolumn{7}{|l|}{$\begin{array}{l}\text { Miasta } 10000 \text { - } 20000 \\
\text { mieszkańców }\end{array}$} \\
\hline $1988 \mathrm{r}$. & 0,175 & 0,097 & $0,026^{a)}$ & 1527,2 & 0,527 & 49.5 \\
\hline $1998 \mathrm{r}$ & 0,225 & 0,137 & $0,099^{b)}$ & 1563,1 & 0,626 & 46,1 \\
\hline \multicolumn{7}{|l|}{$\begin{array}{l}\text { Ogółem miasta do } \\
20000 \text { mieszkańców }\end{array}$} \\
\hline $1988 \mathrm{r}$ & 0,313 & 0,517 & $0,066^{a)}$ & 1601,0 & 0,580 & 59,5 \\
\hline $1998 \mathrm{r}$ & 0,402 & 0,573 & $0,152^{\mathrm{h})}$ & 1579,9 & 0,600 & 61,2 \\
\hline
\end{tabular}

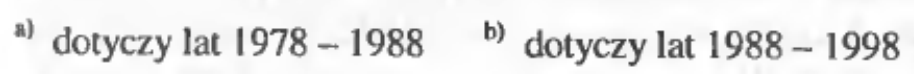

Źródło: jak w tabeli 1; obliczenia własne

Najwyższą wartością współczynnika $(0,099)$ w okresie transformacji gospodarczej charakteryzowały się miasta liczące 10-20 tys. mieszkańców, m. in. Złocieniec $(0,026)$, Bytów (0,023), Darłowo $(0,017)$, Świdwin $(0,015)$ i Człuchów $(0,011)$, co swiadczy o znacznych przekształceniach strukturalnych w przemyśle wymienionych ośrodków.

W mniejszym stopniu podatne na zmiany okazały się jednostki z kategorii wielkościowej od 5000 do 10000 mieszkańców: Czarne $(0,023)$, Karlino $(0,004)$, Połczyn Zdrój 
$(0,002)$, Czaplinek $(0,001)$ i Sianów $(0,001)$. Należy sądzić, iż jest to rezultat nikłego zaawansowania procesów przekształceń strukturalnych $\mathrm{w}$ tej kategorii miast.

Przestrzenne zróżnicowanie wielkości współczynnika redystrybucji wskazuje, że stosunkowo stabilne struktury przemysłowe miały miasta najmniejsze. Omawiany miernik przybierał wartości od 0,001 w Barwicach i Polanowie do 0,005 w Kępicach. Prawdopodobnie mały $w$ nich potencjał przemysłowy okazał się czynnikiem hamującym procesy przemian i w zasadzie utrudniał przystosowanie struktur do nowych warunków gospodarowania.

Okres trwających przekształceń w sposób istotny wpłynął na obniżenie potencjału przemysłowego jednostek, choć ich rozmieszczenie w przestrzeni na ogół nie zmieniło się zasadniczo (ryc.1). Potencjał przemysłowy w dalszym ciągu koncentruje się w miastach położonych w części północnej, wzdłuż szlaku komunikacyjnego Szczecin-Gdańsk. Największymi miastami pod względem liczby pracujących w działalności produkcyjnej w 1998 r. pozostały: Ustka (1,4 tys. pracujących), Sławno (1,2 tys.) i Darłowo (1,2 tys.). Centralny obszar Pomorza Środkowego jest słabiej uprzemysłowiony, tylko Bytów (2,7 tys.) oraz Miastko (1,3 tys.) są większymi ośrodkami produkcyjnymi. Na południowym skraju w pasie równin sandrowych ważną rolę pełni Człuchów (1,7 tys.).

\section{Zmiany struktury wielkości zakładów}

Procesy transformacji gospodarki narodowej w różnym stopniu wpływają na funkcjonowanie jednostek gospodarczych, instytucji i różnej skali jednostek przestrzennych (Zioło 1996). Zjawiska te przyczyniają się $\mathrm{z}$ jednej strony do rozwoju, stagnacji, recesji, a nawet zaniku jednostek $\mathrm{i}$ instytucji, $\mathrm{z}$ drugiej strony wpływają na powstawanie nowych jednostek i instytucji, które w nowych warunkach gospodarowania znajdują sprzyjające warunki dla swojego rozwoju. Szczególnie widoczne zmiany dokonują się w strukturze wielkościowej zakładów. W okresie gospodarki centralnie sterowanej za skuteczną metodę industrializacji uznawano tendencje do budowy dużych zakładów, co również miało miejsce w przypadku małych miast środkowopomorskich. W $1988 \mathrm{r}$. funkcjonowały 4 zakłady przemysłowe zatrudniające ponad 1000 pracowników. Największe przedsiębiorstwo, Stocznia „Ustka” zatrudniało 1235 osób, Przedsiębiorstwo Połowów i Usług Rybackich „Korab” w Ustce 1077 osób, Przedsiębiorstwo Połowów i Usług Rybackich „Kuter” w Darłowie 1003 osoby, a Zakłady Przemysłu Wełnianego w Złocieńcu 1009 osób. Jedną z najwcześniej zauważalnych zmian po $1989 \mathrm{r}$. było stosunkowo liczne pojawienie się (z reguły nowych) drobnych podmiotów gospodarczych, reprezentujących różne formy organizacyjno-prawne, $\mathrm{z}$ dominacją własności prywatnej. W $1998 \mathrm{r}$. wśród 1786 jednostek zarejestrowanych w systemie „Regon” zakłady małe (zatrudniające do 5 osób) stanowiły zdecydowaną większość we wszystkich kategoriach wielkościowych miast. W tym samym roku zakłady duże (zatrudniające powyżej 100 osób) stanowiły niespełna $2,5 \%$ ogólnej liczby firm, lecz zatrudniały w dalszym ciągu $45 \%$ ogółu pracujących w przemyśle.

\section{Procesy prywatyzacji przemyslu}

Istotne przeobrażenia dokonały się również w strukturze własności. W wyniku restrukturyzacji własnościowej przemysłu nastapiła zmiana proporcji posiadania poszczególnych sektorów. Procesy prywatyzacji w małych miastach Pomorza Środkowego, podobnie 
jak w całym kraju, nasiliły się od sierpnia 1990r. wraz z wejściem w życie ustawy o prywatyzacji przedsiębiorstw państwowych. Do tego okresu działalność prowadziło 20 państwowych przedsiębiorstw przemysłowych podległych wojewodzie oraz 6 państwowych przedsiębiorstw przemysłowych, których organem założycielskim był minister. Do końca 1998 r. przekształceniami prywatyzacyjnymi objęto ogółem $69,2 \%$ państwowych przedsiębiorstw przemysłowych. Zdecydowanie największe znaczenie miała prywatyzacja poprzez likwidację. Przewiduje ona wniesienie majątku przedsiębiorstwa do spółki i utworzenie na jego bazie spółki pracowniczej. Tę formę prywatyzacji zastosowano w 2 zakładach funkcjonujących w miastach do 5 tys. mieszkańców (Kępickich Zakładach Garbarskich „Kegar" w Kępicach i Zakładach Przemysłu Welnianego w Bobolicach) oraz w 7 zakładach położonych w ośrodkach liczących powyżej 10 tys. mieszkańców (Fabryce Wyrobów Gospodarstwa Domowego „Zagod” w Bytowie, Zakładach Drobiarskich w Sławnie, Fabryce Maszyn Rolniczych Zakład w Darłowie, Przedsiębiorstwie Przemysłu Betonów „Prefabet” w Kaliszu Pomorskim, Zakładzie Prefabrykacji Betonów w Białym Borze, Fabryce Mebli w Darłowie, Zakładach Przemysłu Wełnianego w Złocieńcu).

Dużo mniejsze znaczenie w działaniach likwidacyjnych miała prywatyzacja kapitałowa, którą objęto tylko 6 przedsiębiorstw zlokalizowanych na terenie omawianych miast. Najwcześniej, bo już w 1991 r. skomercjalizowano Zakłady Sprzętu Instalacyjnego „Polam" w Miastku, następnie w 1992 r. Stocznię w Ustce i Zakłady Przemysłu Dziewiarskiego w Świdwinie. W 1995 r. prywatyzacją pośrednią objęto Fabrykę Rękawiczek i Odzieży Skórzanej w Miastku, Zakłady Płyt Wiórowych i Pilśniowych w Karlinie, a także Fabrykę Maszyn Spożywczych w Połczynie Zdroju.

W rezultacie restrukturyzacji własnościowej przemysłu nastąpił stosunkowo szybki wzrost znaczenia sektora prywatnego. W latach 1988-1998 liczba pracujących w prywatnych zakładach przemysłowych zwiększyła się prawie pięciokrotnie (z 2,7 tys. osób w 1988 r. do 12,2 tys. pracujących w 1998 r.), co spowodowało radykalną zmianę proporcji między sektorem publicznym a prywatnym i to zarówno w przypadku poszczególnych kategorii wielkościowych, jak i ogólnej liczby miast do 20 tys. mieszkańców (ryc.2).

Najbardziej zaawansowane procesy prywatyzacji występują w jednostkach powyżej 10 tys. mieszkańców. Dobrym przykładem działań prywatyzacyjnych są dwa miasta Sławno i Miastko, w których do końca 1998 r. procesem przekształceń własnościowych objęto wszystkie państwowe przedsiębiorstwa przemysłowe. Zdecydowanie najmniej podatne na przekształcenia struktury własnościowej okazały się zakłady w miastach do 5000 mieszkańców. Występują tu duże trudności ze znalezieniem inwestora strategicznego, zdecydowanie niewystarczający jest również udział kapitału zagranicznego, a często także niski poziom akceptacji społecznej. 
1988 r.

1998 r.

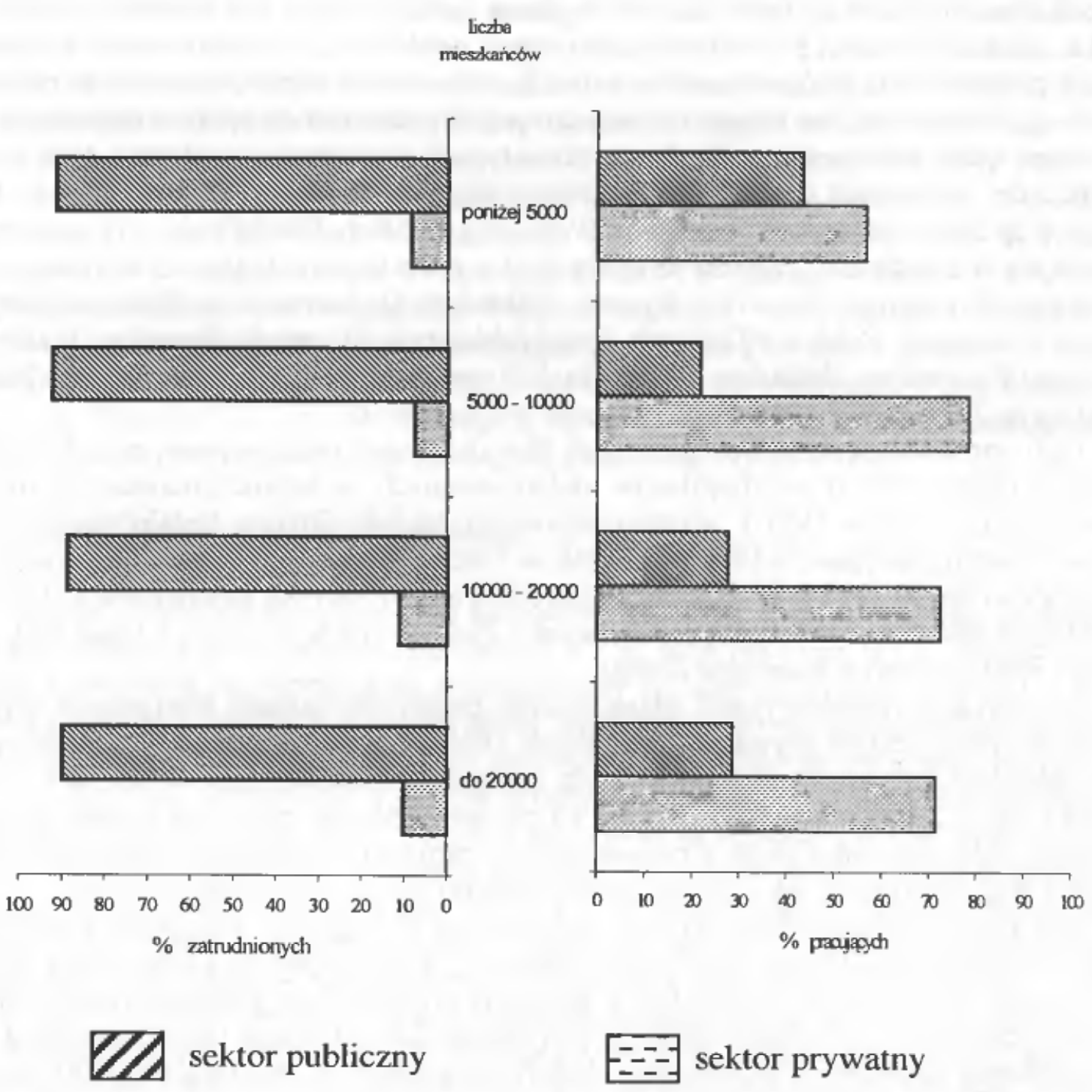

Ryc. 2. Zmiany w strukturze własnościowej przemysłu małych miast Pomorza Środkowego w latach 1988-1998

\section{Zmiany struktury galęziowej przemysłu}

Ważną cechą przemysłu jest jego struktura gałęziowa. Wyraża ona bowiem rolę poszczególnych gałęzi w całym potencjale przemysłowym regionu, a pośrednio świadczy o stopniu jego rozwoju (Rochnacki 1996).

Struktura gałęziowa przemysłu małych miast Pomorza Środkowego ukształtowana została $\mathrm{z}$ jednej strony pod wpływem określonych warunków naturalnych i społecznoekonomicznych występujących na badanym terenie, $\mathrm{z}$ drugiej zaś wynika ze specyficznych 
wymagań lokalizacyjnych poszczególnych branż przemysłu. Zasoby surowców mineralnych Pomorza Środkowego należą do najuboższych w kraju. Pewne znaczenie mają jedynie utwory polodowcowe, tj. iły, gliny, piaski ceramiczne, wykorzystywane przez przemysł budowlany i szklarski, a także pokłady glin i piasków używanych do produkcji ceramiki budowlanej.

Nadmorskie zaś położenie województw słupskiego i koszalińskiego predysponuje omawiany region do rozwoju gospodarki morskiej. Ośrodkiem przemysłu stoczniowego jest Ustka, natomiast rybołówstwo i przetwórstwo rybne zlokalizowane jest oprócz Ustki również w Lebie i Darłowie.

Dzięki zasobom leśnym (39,2\% powierzchni Pomorza Środkowego zajmują lasy) rozwinął się na omawianym obszarze przemysł drzewny, a lokalne surowce pochodzenia rolniczego stały się bazą dla przemysłu spożywczego, reprezentowanego głównie przez przemysł drobiarski (Sławno), mleczarski (Bobolice, Polanów), rybny (Ustka, Darłowo, Łeba) i owocowo-warzywny (Barwice). Te właśnie dziedziny przemysłu dominowały w małych miastach Pomorza Środkowego. Dalsze miejsce zajmował przemysi drzewny, maszynowy, środków transportu i skórzany (ryc.3).

Niemal co drugi zatrudniony w miastach liczących do 5 tys. mieszkańców pracował w zakładzie spożywczym lub skórzanym, gdzie te dwie gałęzie przemysłu skupiały 50,8\% ogólnego zatrudnienia w najmniejszych jednostkach miejskich. Przemysł spożywczy odgrywał szczególną rolę w Lebie, co związane było z funkcjonowaniem Spółdzielni Przetwórstwa i Rybołówstwa Morskiego „Rybmor”, która w 1988 r. zatrudniała 416 osób. W Bobolicach i Polanowie spółdzielnie mleczarskie zatrudniały pod koniec lat osiemdziesiątych po ponad 100 osób każda. Przemysł spożywczy reprezentowały ponadto piekarnie, cukiernie, wytwórnie wód gazowanych oraz masarnie, zlokalizowane najczęściej w każdym mieście. Były to z reguły niewielkie zakłady należące do Gminnych Spółdzielni „Samopomoc Chłopska”. Główną rolę w przemyśle skórzanym pełnił Zakład Garbarski w Kępicach, który w 1988 r. zatrudniał 844 osoby, co stanowiło 83,6\% ogółu pracujących w przemyśle miasta. Specyficzną cechą jednostek najmniejszych był także wysoki poziom specjalizacji w produkcji materiałów budowlanych. Opierając się istniejących zasobach zlokalizowano w Kaliszu Pomorskim i Białym Borze zakłady prefabrykacji betonów, które w 1988 r. zatrudniały łącznie 319 pracowników, i stanowiło to około $11,0 \%$ ogółu pracujących w przemyśle miast do 5 tys. mieszkańców.

Nieco inna była struktura gałęziowa miast liczących 5-10 tys. mieszkańców. W tym przypadku wyraźnie zaznaczyła się dominacja przemysłu drzewnego. Reprezentowały go Zakłady Płyt Wiórowych i Pilśniowych w Karlinie (w 1988 r. zatrudniały 845 osób), a ponadto Sianowskie Zakłady Przemysłu Zapałczanego (w 1988 r. zatrudniały 555 osób). Pewne znaczenie w omawianej kategorii wielkościowej miał także przemysł maszynowy. Do tej gałęzi przemysłu zaliczano produkcję maszyn i urządzeń pralniczych w Debrznie oraz maszyn spożywczych w Połczynie Zdroju. Istotną rolę - jeśli weźmiemy pod uwagę specjalizację gałęziową odgrywał również przemysł materiałów budowlanych. Ważnym ośrodkiem tej gałęzi przemysłu były zakłady wytwarzające elementy $\mathbf{z}$ betonu dla budownictwa ogólnego, przemysłowego i niekubaturowego w Czarnem. W Przedsiębiorstwie Prefabrykacji nr 2 i Gospodarstwie Pomocniczym TYP 09 przy Zakładzie Karnym pracowało bowiem w 1988 r. łącznie 1345 osób. 


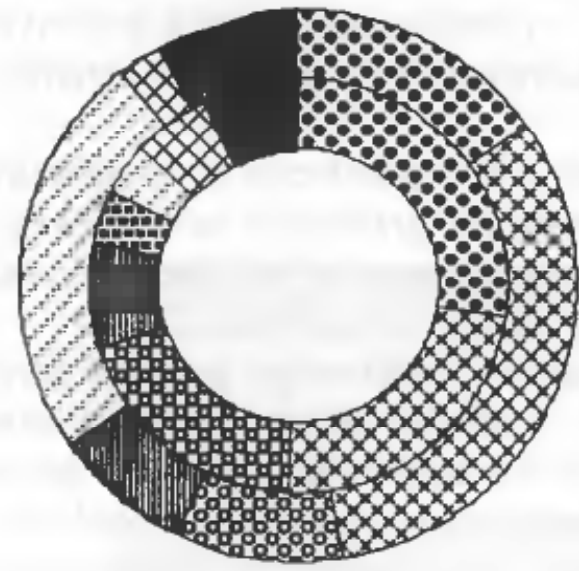

Miasta do 5000 mieszknnców

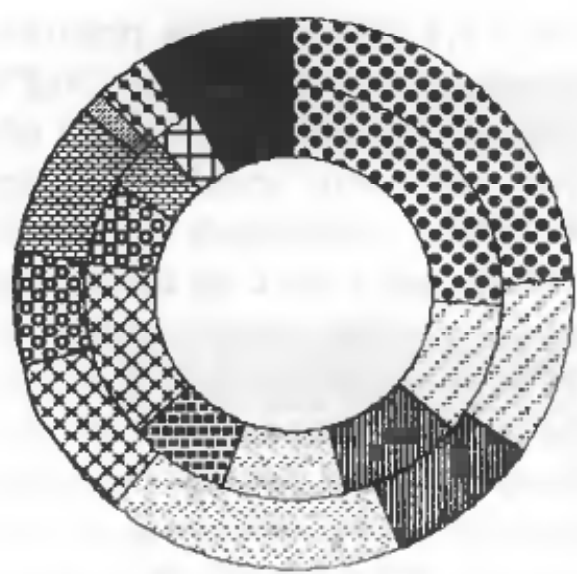

Miasta 10000-20000 mieszkariów

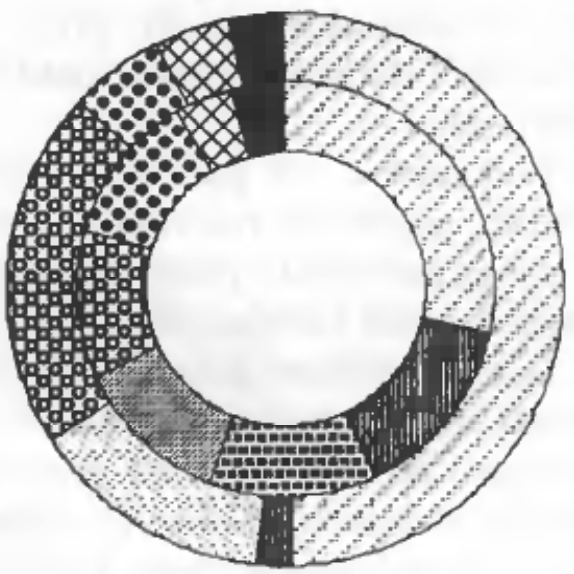

Minata 5000-10000 micazknhobw

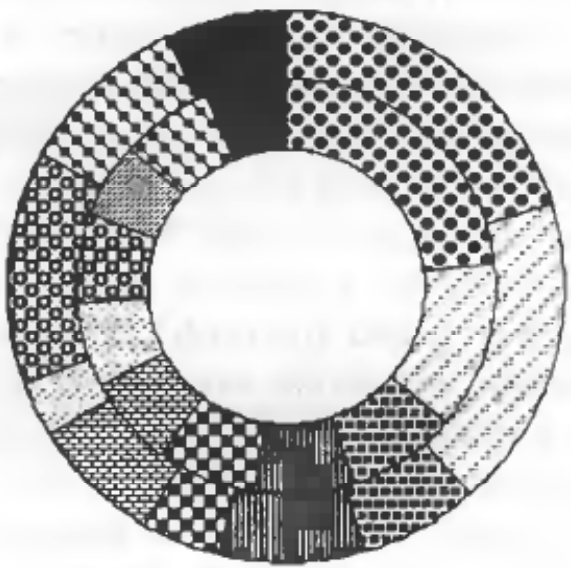

Ogólem miaste do 20000

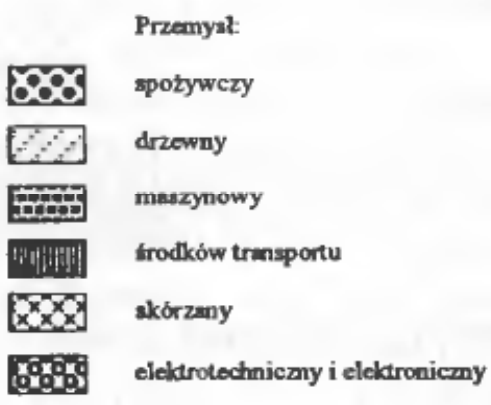

\begin{tabular}{|c|c|}
\hline$\ldots$ & odziezowy \\
\hline 㯺 & materialów budowlenych \\
\hline$x$ & paszowy i utylizacyjiny \\
\hline & papiemiczy \\
\hline & chemicmy \\
\hline & pozodel \\
\hline
\end{tabular}

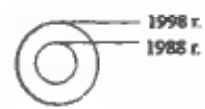

Ryc.3. Zmiany w strukturze gałęziowej przemysłu w małych miastach Pomorza Środkowego w latach 1988-1998. 
Największą dywersyfikacją przemysłu odznaczały się miasta z kategorii powyżej 10 tys. mieszkańców. Z dotychczasowych badań wynika, że obok zakładów przemysłu spożywczego oraz drzewnego najwyższy udział miały przedsiębiorstwa przemysłu lekkiego. Nie wymagał on zbyt wysokich nakładów finansowych na rozbudowę urządzeń infrastruktury technicznej, a zapewniał miejsca pracy dla kobiet. W przypadku regionu środkowopomorskiego ma to również podłoże historyczne. Do dziś bowiem Drawsko Pomorskie i Złocieniec funkcjonują jako ośrodki przemysłu odzieżowego. Obok historycznie ukształtowanych zespołów przemysłu lekkiego powstały w pasie pobrzeża nowe zakłady, reprezentowane przez Odzieżową Spółdzielnię Pracy „Sławianka” w Sławnie (163 osoby w 1988 r.), czy Fabrykę Rękawiczek i Odzieży Skórzanej w Miastku (918 osoby w 1988r.). Generalnie małe miasta Pomorza Środkowego charakteryzują się niskim stopniem zróżnicowania gałęziowego przemysłu, co potwierdzają współczynniki dywersyfikacji (tab.2). Dodatkowo są to ośrodki wyspecjalizowane w jednej lub dwu gałęziach przemysłu.

Z przeprowadzonych badań wynika, że przeobrażenia w strukturze gałęziowej przemysłu w pierwszych latach transformacji gospodarczej dokonywały się na ogół wolniej aniżeli w przypadku struktury własnościowej i wielkościowej. Zjawisko to potwierdza wyrównany wskaźnik Rodgersa ${ }^{3 /}$ (tab.2). Pewne zmiany zaobserwować można w strukturze rodzajowej działalności produkcyjnej. Obok tradycyjnych gałęzi przemysłu, które w okresie transformacji gospodarczej umocniły swoją pozycję, pojawiły się nowe rodzaje działalności, m. in. zakłady chemiczne i poligraficzne.

Jakkolwiek w latach 1988-1998 nie nastapiły fundamentalne zmiany w strukturze gałęziowej małych miast Pomorza Środkowego, to relatywnie najszybciej w tym czasie rosło zatrudnienie w przemyśle spożywczym, drzewnym i lekkim, głównie kosztem przemysłu elektromaszynowego (ryc.3). Drastyczny spadek zatrudnienia aż do całkowitego zaniechania produkcji miał miejsce w przemyśle paszowym i utylizacyjnym. Ma to ścisły związek $\mathrm{z}$ głęboką recesją w rolnictwie uspołecznionym, a w konsekwencji z bankructwem państwowych gospodarstw rolnych (Rydz 1995). Najwcześniej na sytuację kryzysową zareagował przemysł materiałów budowlanych. Było to konsekwencją utraconych zdolności rozwojowych gospodarki. Pewne ograniczenie zatrudnienia nastąpiło także w przemyśle środków transportu, co należy wiązać głównie ze zmniejszonym popytem na wyroby Stoczni „Ustka”. Nadmienić należy, że w szczytowym okresie produkcji (w końcu lat siedemdziesiątych) Stocznia „Ustka” wodowała 19 jednostek stalowych i 5 holowników rocznie. Około $70 \%$ produkcji sprzedawano do ZSRR, pozostałe $30 \%$ wybudowanych jednostek trafiało na rynek polski, rumuński i do NRD. Wprowadzenie reguł gospodarki rynkowej i utrata dotychczasowych rynków zbytu były zasadniczą przyczyną załamania produkcji i sprzedaży Stoczni „Ustka”. W okresie kryzysu uruchomiono co prawda produkcję przenośnych kiosków handlowo-usługowych, kabin natryskowych, pojemników plastikowych i siedzisk stadionowych, jednak nie pozwoliło to utrzymać zatrudnienia na poziomie z końca lat osiemdziesiątych. W latach 1988-1998 zatrudnienie w Stoczni zmniejszyło się o około $67,0 \%$.

Liczba podmiotów gospodarczych działających w przemyśle jest także ważnym miernikiem charakteryzującym potencjał przemysłowy jednostek. Biorąc pod uwagę wymieniony wskaźnik na podstawie przeprowadzonych badań stwierdzić naležy, iż w pierwszej fazie transformacji (1989-93) liczba podmiotów zwiększyła się prawie pięciokrotnie (tab.3), natomiast w latach 1993-1998 utrzymuje się na zbliżonym poziomie. Największą koncen- 
tracją podmiotów przemysłowych w 1998 r. odznaczały się miasta powyżej 10 tys. ludności $(68,3 \%)$.

Z uzyskanych materiałów wynika, że w 1998r. najliczniejszą grupę stanowiły podmioty związane z produkcją artykułów spożywczych. Należy podkreślić, że wśród zakładów spożywczych przeważają podmioty związane z produkcją pieczywa, wędlin i ryb.

Drugą grupę tworzyły podmioty związane z produkcją odzieży. Aktualnie są to z reguły sprywatyzowane spółdzielnie odzieżowe, które pełniły funkcje usługowe w dziedzinie krawiectwa. Obecnie produkują one głównie odzież dla kontrahentów zagranicznych, najczęśsiej z tkanin przez nich dostarczanych. Rozmieszczenie tych zakładów wskazuje, iż głównym czynnikiem ich lokalizacji jest wykwalifikowana siła robocza. Produkcję konfekcji damskiej z materiałów powierzonych na rynck niemiecki, włoski prowadzi "Sławotex" Zakład Odzieżowy w Sławnie, „Regatex” Spółka z o.o. w Świdwinie, Przedsiębiorstwo Produkcyjno-Handlowe „Elita” w Bytowie.

Nieco odmienny profil produkcji ma Zakład Odzieżowy „Drawa STD” Spółka z o.o. z siedzibą w Złocieńcu. W 1998 r. łącznie z filią zakładu w Drawsku Pomorskim zatrudnionych tam było 528 osób. Zakład Odzieżowy w Złocieńcu szyje odzież dla służb medycznych, natomiast drawieńska filia specjalizuje się w produkcji odzieży roboczej. Prawie cały asortyment wyrobów „Drawy STD” znajduje zbyt na rynku niemieckim. Produkcją odzieży roboczej zajmuje się także Odzieżowa Spółdzielnia Inwalidów „Przymorze” w Sławnie. Jest to zakład pracy chronionej, w którym na koniec 1998 r. pracowało 251 osób. Na wyróżnienie wśród małych miast środkowopomorskich związanych z produkcją odzieży zasługuje Miastko. W Fabryce Rękawiczek i Odzieży Skórzanej „TINOS” Spółka z o.o. przy współudziale kapitału włoskiego produkuje się rękawiczki i odzież ze skór naturalnych na rynki zachodnie.

Kolejną grupę wśród podmiotów związanych z działalnością produkcyjną tworzą zakłady reprezentujące produkcję z drewna. Rozwój przemysłu drzewnego, choć ma na Pomorzu Środkowym długie tradycje, to w małych miastach jego intensywny rozwój nastapił na początku lat dziewięćdziesiątych. Ze względu na relatywnie niski poziom cen, po jakich oferowano wyroby do krajów Unii Europejskiej, rozwinęły działalność małe i średnie przedsiębiorstwa prawie w każdym małym mieście środkowopomorskim. Zdecydowana większość z nich zajmuje się produkcją palet oraz galanterii ogrodowej. Najliczniej podmioty związane z produkcją drewna występują w Drawsku Pomorskim, Miastku, Kaliszu Pomorskim, Bytowie, Sławnie, Świdwinie oraz Czaplinku. Z okresu gospodarki centralnie sterowanej pozostały jedynie 2 duże przedsiębiorstwa: Sławieńskie Zakłady Przemysłu Drzewnego przekształcone 26.02.1992 r. w „Sławodrzew” Spółka z o.o., które w dalszym ciągu zajmują się cięciem i heblowaniem, impregnacją drewna, produkcją opakowań drewnianych oraz sprzedażą hurtową drewna i materiałów budowlanych. Drugim dużym przedsiębiorstwem pozostały Zakłady Płyt Wiórowych i Pilśniowych w Karlinie. Do końca 1995 r. pozostawały w rejestrze przedsiębiorstw państwowych.

Zdecydowanie mniejszy potencjał mają podmioty związane z produkcją wyrobów gotowych z metali. Ich rozmieszczenie wyraźnie nawiązuje do rynków zbytu. Podmioty tej podsekcji przeważają w miastach liczących 10-20 tys. mieszkańców. W 1998 r. ta kategoria ośrodków koncentrowała $92,2 \%$ ogółu pracujących w małych miastach i 70,6\% podmiotów gospodarujących w branży metalowej. 
Ważnym ośrodkiem związanym z przemysłem metalowym jest Bytów. Znajdują się tu Zakłady Konstrukcji Stalowych i Urządzeń Elektrycznych „Polmor”, Spółdzielnia Pracy Przemysłu Metalowego „Postęp”, Spółdzielnia Inwalidów „Metal” oraz Przedsiębiorstwo Produkcyjno-Handlowo-Usługowe „AG Metal”. Na wyróżnienie zasługuje „Polmor”, który produkuje palniki olejowe wraz z kompletną automatyką kotłów wodnych i parowych, na rynek krajowy, a także na eksport do Niemiec i Holandii. Ważnym przedsiębiorstwem z udziałem kapitału amerykańskiego jest FCPK Spółka z o.o. produkująca części do form natryskowych. Znacznie mniejszą koncentrację zakładów metalowych mają Człuchów, Świdwin i Złocieniec.

Kolejną grupę stanowią pomioty związane z produkcją maszyn i urządzeń. Zakłady te zlokalizowane są głównie w miastach liczących powyżej 5 tys. mieszkańców, co związane jest z nadwyżkami siły roboczej. Do wyróżniających się należą: „Argos” w Bytowie, „Demeth-Wuteh" w Debrznie, Fabryka Maszyn Spożywczych SA w Połczynie Zdroju.

Prawie 7\% podmiotów zajmuje się produkcją środków transportu. Głównym producentem sprzętu transportowego pozostaje w dalszym ciagu Stocznia „Ustka” SA Nowym zaś podmiotem gospodarczym w tej dziedzinie przemysłu są Zakłady Rowerowe „Kołaszewski” w Bytowie, powstałe na bazie majątku Państwowego Ośrodka Maszynowego. Zakład ten zatrudnia około 200 osób.

Do branż o najniższym udziale pracujących w strukturze działalności produkcyjnej małych miast Pomorza Środkowego w 1998 r. należały podmioty związane z produkcją masy celulozowej, papieru oraz wyrobów z papieru $(0,9 \%$ ogółu pracujących w działalności produkcyjnej), działalnością wydawniczą poligraficzną i reprodukcją zapisanych nośników informacji $(0,9 \%)$, produkcją metali $(0,6 \%)$, produkcją chemikaliów, wyrobów chemicznych i włókien sztucznych $(0,3 \%)$ oraz produkcją instrumentów medycznych, precyzyjnych i optycznych, zegarów i zegarków $(0,2 \%)$.

Przeprowadzona analiza wykazała, że znaczenie przemysłu jako czynnika miastotwórczego w okresie transformacji gospodarczej uległo wyraźnemu ograniczeniu we wszystkich kategoriach wielkościowych miast. Obecnie jednostki o wyspecjalizowanej funkcji przemysłowej przeżywają kryzys podstaw gospodarczych. 


\section{Dat}




\section{Przypisy}

${ }^{1}$ Wskaźnik specjalizacji względnej określono według wzoru:

$$
S_{w}=\frac{1}{200} \sum_{i=1}^{n}\left|g_{i}-G_{i}\right|
$$

$g_{i}$ - procentowy udział i-tej gałęzi w strukturze gałęziowej miasta

$G_{i}$ - procentowy udział i-tej gałęzi w strukturze gałęziowej ogółu małych miast Pomorza Środkowego.

${ }^{2}$ Współczynnik redystybucji określono według wzoru:

$$
W r=\frac{1}{200} \sum_{i=1}^{n}\left|p_{i}^{t_{0}}-p_{i}^{t_{1}}\right|
$$

$p_{i}$ - procentowy udział zatrudnionych w przemyśle małego miasta w stosunku do ogołu małych miast Pomorza Środkowego w $t_{0} i t_{l}$ przekroju czasowym

${ }^{3}$ Wyrównany wskaźnik Rodgersa obliczono według wzoru:

$$
I_{m}=\frac{S_{\text {ind }}-S_{\text {min }}}{S_{\text {max }}-S_{\text {min }}}
$$

$S_{\text {ind }}$ - wartość surowego wskaźnika Rodgersa

$S_{\max }-$ iloczyn liczby rozpatrywanych gałęzi x $100 \quad S_{\min }-1 / 2 S_{\max }+50$ 


\section{Literatura}

Ginsbert-Gebert A., Mate miasta i przestanki ich rozwoju. - Gospodarka i administracja terenowa 5

Kiełczewska-Zaleska M., 1963, Osadnictwo. W: Geografia Powszechna t. II. Warszawa

Liszewski S., 1993, Dorobek tódzkiego ośrodka geograficznego w zakresie badania ośrodków lokalnych. Próba syntezy, kierunki dalszych prac. W: Problematyka lokalnych systemów osadniczych, red. W. Maik. Toruń

Myna A., 1993, Przemyst w małych miastach. Człowiek i Środowisko, nr 2-3

Rajman J., 1977, Miejsce małych miast w systemie osadniczym województwa opolskiego. Studia Śląskie, Seria nowa, tom XXXII

Rajman J., 1989, Wphyw przemystu na zmiany w sieci $i$ funkcjach miast (na przykładzie miast makroregionu południowego). W: Studia nad urbanizacją południowej Polski. Prace Monograficzne. WSP Kraków

Rochnacki H., 1996, Przemysl, W: Województwo toruńskie i wrocławskie w okresie transformacji systemowej. Diagnoza w skali regionalnej, red. S. L. Bagdziński, W. Maik i A. Potoczek, Toruń

Rydz E., 1981, Miejsce matych miast w systemie osadniczym Pomorza Środkowego. Słupskie Prace Matematyczno-Przyrodnicze, nr 2

Rydz E., 1995, Rozmiary $i$ struktura bezrobocia $w$ województwie stupskim. W: Zadania badawcze geografii społecznej i ekonomicznej w obliczu transformacji ustrojowej i restrukturyzacji gospodarczej (materiały z konferencji), red. A. Jagielski, WrocławSzklarska Poręba

Zioło Z., 1996, Oddzialywanie procesów transformacji gospodarki narodowej na funkcjonowanie jednostek gospodarczych i uktadów przestrzennych, red. Z. Zioło, WarszawaKraków

Żechowski Z. A., 1973, Przemiany matych miast w procesie uprzemystowienia. Poznań

\section{Wykaz rycin}

1. Tendencje zmian funkcji przemysłowej małych miast Pomorza Środkowego w latach 1988-1998

2. Zmiany w strukturze własnościowej przemysłu małych miast Pomorza Środkowego w latach 1988-1998

3. Zmiany w strukturze gałęziowej przemysłu w małych miastach Pomorza Środkowego w latach 1988-1998 